\title{
Pathology of dogs in Campo Grande, MS, Brazil naturally co-infected with Leishmania infantum and Ehrlichia canis
}

\author{
Patologia de cães naturalmente coinfectados por Leishmania infantum e \\ Ehrlichia canis em Campo Grande, MS, Brasil
}

Gisele Braziliano Andrade ${ }^{1 *}$; Wanessa Teixeira Gomes Barreto ${ }^{1}$; Luciana Ladislau dos Santos ${ }^{1}$;

Laura Raquel Rios Ribeiro ${ }^{1}$; Gabriel Carvalho de Macedo ${ }^{1}$; Keyla Carstens Marques de Sousa ${ }^{2}$; Marcos Rogério André2; Rosangela Zacarias Machadoº ${ }^{2}$ Heitor Miraglia Herrera ${ }^{1}$

\author{
${ }^{1}$ Universidade Católica Dom Bosco - UCDB, Campo Grande, MS, Brasil \\ ${ }^{2}$ Faculdade de Ciências Agrárias e Veterinárias - FCAV, Universidade Estadual Paulista - UNESP, Jaboticabal, SP, Brasil
}

Received August 08, 2014

Accepted September 01, 2014

\begin{abstract}
Different parasites that commonly occur concomitantly can influence one another, sometimes with unpredictable effects. We evaluated pathological aspects of dogs naturally co-infected with Leishmania infantum and Ehrlichia canis. The health status of the dogs was investigated based on histopathological, hematological and biochemical analyses of 21 animals infected solely with L. infantum and 22 dogs co- infected with L. infantum and E. canis. The skin of both groups showed chronic, predominantly lymphohistioplasmacytic inflammatory reaction. The plasmacytosis in the lymphoid tissues was likely related with the hypergammaglobulinemia detected in all the dogs. The disorganization of extracellular matrix found in the reticular dermis of the inguinal region and ear, characterized by the substitution of thick collagen fibers for thin fibers, was attributed to the degree of inflammatory reaction, irrespective of the presence of parasites. In addition, the histopathological analysis revealed that twice as many dogs in the co-infected group presented Leishmania amastigotes in the ear skin than those infected solely with Leishmania, increasing the possibility of becoming infected through sand fly vectors. Our findings highlight the fact that the health of dogs infected concomitantly with L. infantum and E. canis is severely compromised due to their high levels of total plasma protein, globulins, alkaline phosphatase and creatine kinase, and severe anemia.
\end{abstract}

Keywords: Canine leishmaniasis, canine ehrlichiosis, histopathology, concomitant infections.

\section{Resumo}

A infecção simultânea por parasitas de diferentes espécies pode resultar em alteraçóes imprevisíveis. O presente estudo avaliou a patologia de cães naturalmente coinfectados por Leishmania infantum e Ehrlichia canis. A saúde dos cães foi investigada pelas análises histopatológicas, hematológicas e bioquímicas de 21 cães infectados somente por L. infantum e 22 cães coinfectados por L. infantum e E. canis. Observou-se uma reação inflamatória crônica, predominantemente linfohistioplasmocítica, na pele dos dois grupos. A plasmocitose, encontrada nos tecidos linfóides, provavelmente estava relacionada com a hipergamaglobulinemia observada em todos os cães amostrados. A desorganização da matriz extracelular da derme da região inguinal e da orelha, demonstrada pela substituição das fibras de colágeno espessas por fibras finas, foi relacionada com o grau de reação inflamatória, independente da presença de parasitas. Ainda, observamos duas vezes mais animais do grupo coinfectado apresentando formas amastigotas na pele de orelha pela histopatologia comparado ao número de cães infectados apenas por Leishmania, tornando-os desta forma mais infectivos aos vetores. Nossos resultados ressaltam que a saúde de cães coinfectados estava severamente comprometida devido aos altos níveis de proteína plasmática total, globulinas, fosfatase alcalina, creatina quinase e anemia acentuada.

Palavras-chave: Leishmaniose canina, erliquiose canina, histopatologia, infecçôes concomitantes. 


\section{Introduction}

Canine visceral leishmaniasis (CVL) and canine monocytic ehrlichiosis (CME) are severe arthropod-borne diseases caused, respectively, by the obligatory intracellular pathogens Leishmania infantum and Ehrlichia canis. Whereas L. infantum is transmitted by phlebotomine sand flies, mostly Lutzomyia longipalpis, E. canis is transmitted by ticks, mainly Rhipicephalus sanguineus (REY, 2001; NICHOLSON et al., 2010). Since these pathogens can also infect humans, dogs play an important role in human epidemiology of these diseases because they are source of arthropod vector-borne infections (UNVER et al., 2001; ISMAIL et al., 2010; DAY, 2011).

Different organisms often occur concomitantly in the same host, influencing one another directly or indirectly and resulting in a range of interactions with the host's immune status, parasite strains and environmental conditions. The pathogenesis of any specific parasite in an individual host co-infected with another parasitic species may be very different from an infection caused by the same parasites in another individual host. These facts constitute a number of implications for the epidemiological and clinical aspects of human and veterinary parasitology (COX, 2001).

Health impairment caused by immunosuppression due to co-infection with pathogens that replicate inside mononuclear phagocytes, such as Leishmania and Ehrlichia, may lead to the increase in parasitemia because natural immunity against these agents is usually quite ineffective in controlling the colonization and dissemination of these microorganisms (GARRAUD et al., 2003). This phenomenon is especially important because the transmission of hemoparasites is directly associated with high parasitemia and/or skin parasitism, which favors arthropod vector-borne infections.

In addition, both of these infectious agents disseminate from the skin to the spleen, liver and bone marrow, activating host immune mechanisms and inducing a broad range of clinical and immunopathological responses ranging from asymptomatic infection to chronic wasting disease and culminating in death. This can be explained by the type of immune response. In this context, previous studies have found that asymptomatic Leishmania infected dogs produce a T-helper Th1-cell mediated response, while clinically affected Leishmania-infected dogs generate a Th2mediated response (PINELLI et al., 1994). Recent studies have shown that the Th1/Th2 paradigm is an oversimplification of a far more complicated network of regulatory/counter-regulatory interactions, which differ according to the individual host and the tissue site examined (ALEXANDER \& BRYSON, 2005; ALEXANDER \& BROMBACHER, 2012).

The synergism caused by intramonocytic pathogens, and the consequent suppression of the immune system, represent a threat to the health of infected animals (GARRAUD et al., 2003; DE TOMMASI et al., 2013). Since dogs in Campo Grande, state of Mato Grosso do Sul, Brazil, are exposed to multiple tick-borne pathogens (DE SOUSA et al., 2013), the aim of this study was to evaluate the clinical and pathological condition by comparing $L$. infantum infected dogs with or without $E$. canis co-infection, based on histological, hematological and biochemical analyses.

\section{Materials and Methods}

\section{Animals}

Samples were taken from dogs previously diagnosed through serological and molecular tests (DE SOUSA et al., 2013). We considered positive for CVL and CME only animals that tested positive in both serological and molecular tests, which resulted in 21 animals monoinfected with $L$. infantum (Group 1 - G1) and 22 co-infected with $L$. infantum and E. canis (Group $2-\mathrm{G} 2$ ).

This study was approved by the Ethics Committee of the Catholic University Dom Bosco (CEUA/UCDB, no. 001/11). Appropriate biosafety techniques and individual protection equipment were used during all the procedures of collection and handling of biological samples.

\section{Histopathological techniques}

Necropsies were performed at the Department of Animal Pathology of the Catholic University Dom Bosco (UCDB) Veterinary Hospital. Fragments of inguinal and ear skin, spleen and lymph node of animals were collected and tissues were processed by the usual histology slide preparation techniques, stained with hematoxylin and eosin (HE) and Masson's Trichrome (MT) for light microscopy analysis (LUNA, 1968).

The inflammatory infiltrate was graded as follows: (-) - no inflammatory infiltrate; discrete $(+)$ - isolated foci of inflammatory cells; moderate $(++)$ - isolated coalescent areas of inflammatory infiltrate; and intense $(+++)$ - diffuse areas of inflammatory infiltrate (SOLANO-GALLEGO et al., 2004). We also investigated the presence of amastigote forms of Leishmania in skin. The parasite load was determined in skin sections as the average number of microorganisms counted in five 400x fields of areas with inflammatory infiltrate: absent - no microorganisms; discrete $(+)$ 1-10; moderate $(++) 11-30$; and intense $(+++)>30$ (RIDLEY \& RIDLEY, 1983).

The main morphologically relevant changes observed in the lymphoid tissues and skin sections are described below.

\section{Hematological and biochemical analysis}

The packed cell volume (PCV) was determined by the microhematocrit method, hemoglobin concentration using a LABTEST ${ }^{\circledast}$ kit, red blood cell (RBC) and white blood cell (WBC) count using a Neubauer chamber, and the leukocyte differential count was carried out in blood smears stained using a Panoptic ${ }^{\circledR}$ kit. The total plasma protein (TPP) concentration was determined spectrophotometrically using microhematocrit capillary tubes in a spectrophotometer (Quimis).

Serum concentrations of urea, creatinine, albumin, alkaline phosphatase (AP), alanine aminotransferase (ALT) and creatine kinase $(\mathrm{CK})$ were determined by spectrophotometric analysis using Biotech ${ }^{\circledR}$ and Gold ${ }^{\circledR}$ commercial kits. Globulin values were determined based on the difference between TPP and albumin values (CASTRO et al., 2012). 
The means of hematological and biochemical values of both G1 and G2 were compared by the nonparametric MannWhitney test at $95 \%$ level of confidence. Also, the influence of $L$. infantum and the co-infection with $L$. infantum and E. canis in haematological and biochemical parameters were evaluated by analysis of variance using Kruskal-Wallis test. We used the hematological and biochemical values described by Jain (1993) and Kaneko et al. (1997), respectively, as reference values for domestic dog species.

\section{Results}

\section{Histological analysis of inguinal and ear skin}

Amastigote forms of Leishmania were identified in skin sections of both groups. The parasite intensity was variable but frequently discrete. The percentage of dogs in G2 that presented Leishmania amastigotes in ear skin (36\%) was almost double that of dogs in G1 (19\%) (Figure 1a). No association was found between the intensity of inflammatory infiltrate and the intensity of parasite load, or among the animals of either G1 or G2. Moreover, no association was detected between serological titers (data not shown) and the presence of amastigote forms of Leishmania in skin samples.

In general, the sampled animals showed variations in the degree of inflammatory reaction in skin. Both Leishmania infected (G1) and Leishmania and Ehrlichia co-infected (G2) animals showed a predominance of mononuclear (lymphocytes, macrophages and plasma cells) dermatitis (Figure 1a) of variable intensity, distributed around vessels and hair follicles. Mott cells, more frequently found in the ear skin of G1 animals, were also observed. Degradation and scantiness of collagen fibers was observed in areas of dermal inflammation (Figure 1b), where thick collagen fibers were replaced by thin fibers in the reticular dermis of inguinal and ear skin tissues (Figure 1c).

\section{Histological analysis of lymphoid tissues}

Capsular inflammation was frequent in spleen and lymph nodes of both groups, composed predominantly of mononuclear cells (lymphocytes, histiocytes and plasmocytes). The inflammatory infiltrate was classified as discrete (44\%) in G1 and moderate (50\%) in G2. Twenty-seven percent of all infected animals presented proliferation of collagen fibers in the splenic capsule (Figure 2a).

The inflammatory reaction in the white pulp of the animals of both groups was predominantly histiocytic, ranging from mild to moderate. Furthermore, 32\% of G2 and 57\% of G1 showed structural disorganization of the white pulp region. White pulp hypoplasia was observed in animals of both groups (Figure 2b), while lymphoid follicles and white pulp hyperplasia (Figure 2b) were detected in $50 \%$ of the animals. Most of the animals in both groups presented an increased number of arterioles in the white pulp (Figure 2c). Granulomas (Figure 2d) and microhemorrhages were observed in $50 \%$ of both groups. In addition, Mott cells were observed in two animals of G2.

In the cortical/paracortical and medullary region of lymph nodes, the inflammatory reaction was lymphohistioplasmacytic, moderate to intense in G1 and moderate in G2. In addition, Mott cells were present in $40 \%$ of G2 and 14\% of G1 (Figure 2e). Masson's trichrome (MT) stain revealed fibrosis in the parenchyma (Figure 2f) and vascular fibroplasia in 20\% of all lymph node samples.

\section{Serum biochemistry and hematological analysis}

Normocytic normochromic anemia and thrombocytopenia were constant features found in groups G1 and G2 (Table 1). Anemia was strongly evident in co-infected dogs, characterized by lower than normal RBC, $\mathrm{Ht}$ and $\mathrm{Hg}$ values (Table 1) (JAIN, 1993). In addition, the biochemical analysis indicated that the average values of TPP, AP, globulin and CK in both groups were higher than the reference values (Table 1) (KANEKO et al., 1997). We observed that albumin, AP and Ht values differed significantly between G1 and G2.

\section{Discussion}

This study found chronic inflammatory reaction, predominantly lymphocytic and histoplasmocytic, in the skin of both groups, as previously reported (DOS SANTOS et al., 2004;
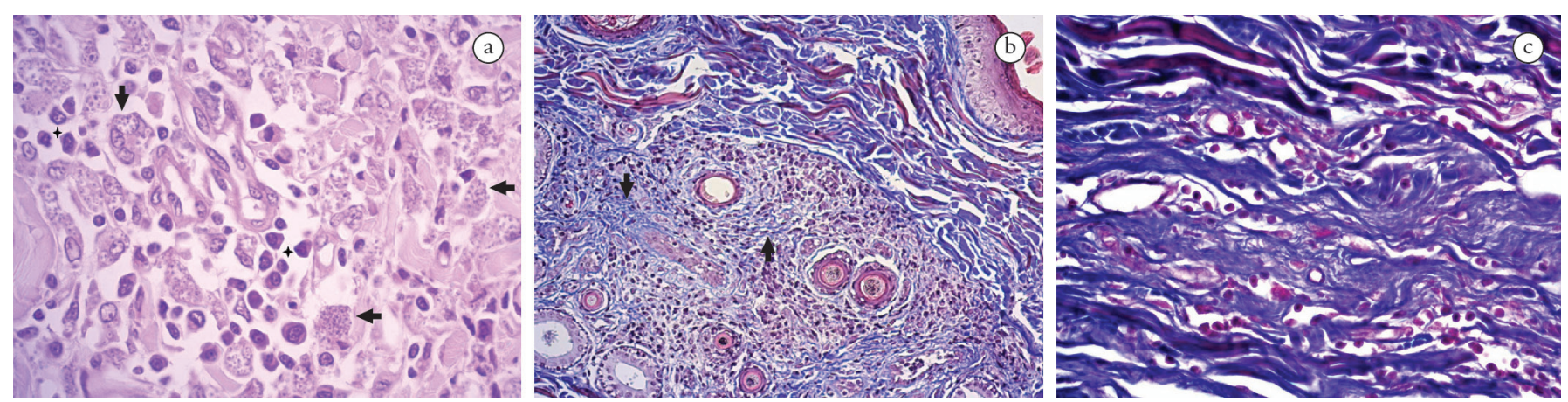

Figure 1. Morphological changes in tissues of dogs naturally infected with L. infantum and E. canis. (a) Ear skin. Representative lymph histoplasmocytic infiltrate (stars) and amastigote forms (arrows) in a monoinfected dog (HE, 630x). (b) Ear skin. Representative degradation and lack of collagen fibers in inflammatory areas (arrows) of the reticular dermis of a co-infected dog (MT, 100x). (c) Inguinal skin. Representative thin fibers replacing thick collagen fibers in the reticular dermis of a monoinfected dog (MT, 630x). 

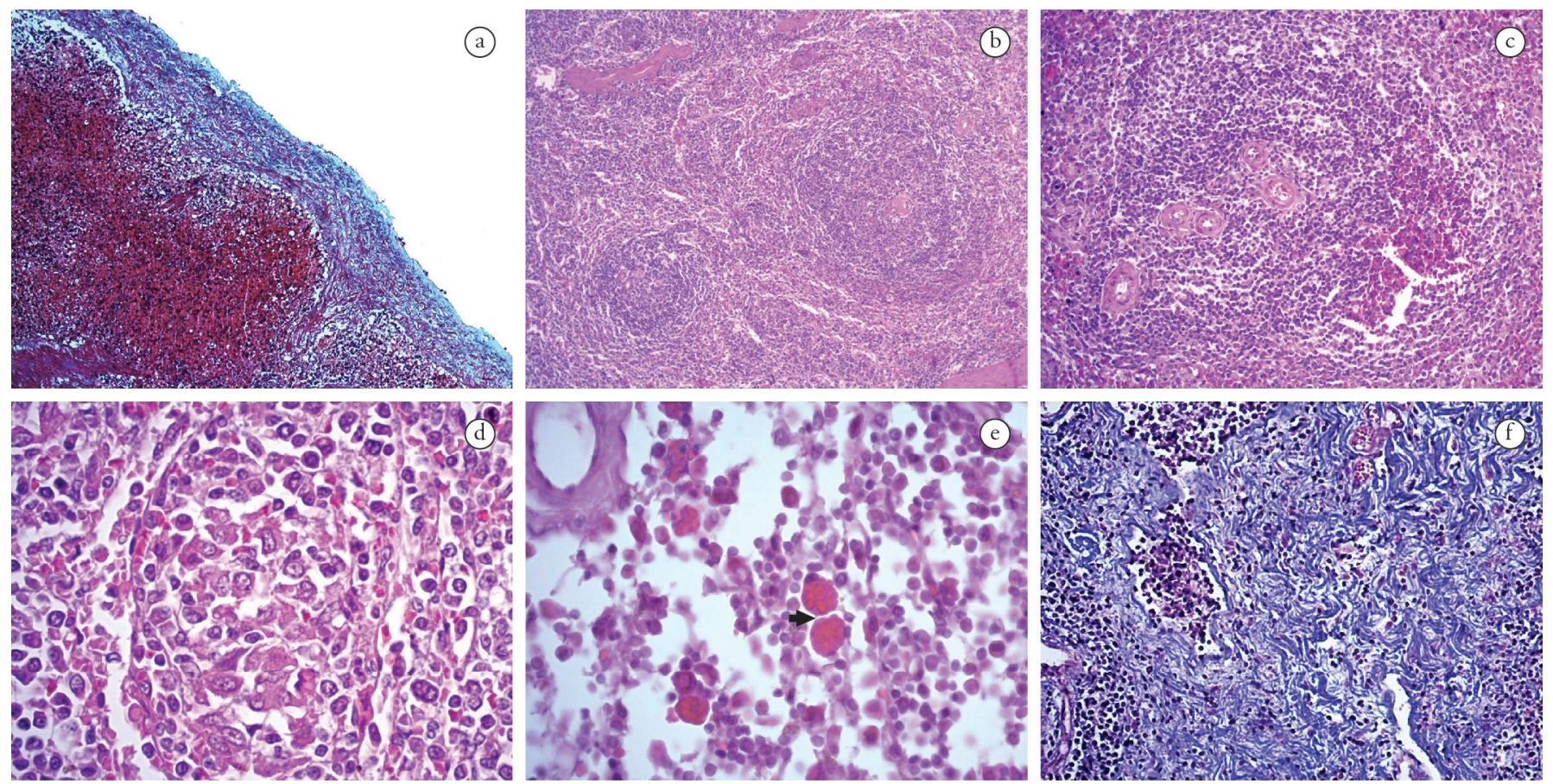

Figure 2. Morphological changes in lymphoid tissues of dogs naturally infected with L. infantum and E. canis. (a) Spleen. Representative thickness of capsule due to collagen fiber proliferation in a mono-infected dog (MT, 100x). (b) Spleen. Representative hyperplasia and hypoplasia of the white pulp of a co-infected dog (HE, 50x). (c) Spleen. Representative increased number of arterioles of a dog monoinfected (HE, 100x). (d) Spleen. Representative granuloma from a co-infected dog (HE, 400x). (e) Lymph node. Representative Mott cells (arrow) of a monoinfected $\operatorname{dog}(\mathrm{HE}, 630 \mathrm{x})$. (f) Lymph node. Representative fibrosis in the parenchyma of a monoinfected dog (MT, 200x).

Table 1. Hematological and biochemical values of dogs naturally infected only by Leishmania infantum (G1) and with (G2) concomitant infection by Ehrlichia canis in Campo Grande, MS.

\begin{tabular}{lccc}
\hline \multirow{2}{*}{ Parameter } & Leishmania-infected & Co-infected & Reference values $^{\mathbf{1}}$ \\
\cline { 2 - 3 } & dogs $(\mathbf{G} \mathbf{1})$ & dogs $(\mathbf{G} 2)$ & $5.4-7.1$ \\
TPP $(\mathrm{g} / \mathrm{dl})$ & $12.6 \pm 1.5$ & $12.9 \pm 2.2$ & $2.6-3.3$ \\
Albumin $(\mathrm{g} / \mathrm{dl})$ & $2.5 \pm 1.5^{\mathrm{a}}$ & $1.8 \pm 0.5^{\mathrm{a}}$ & $2.7-4.4$ \\
Globulin $(\mathrm{g} / \mathrm{dl})$ & $10.2 \pm 2.1$ & $11.1 \pm 2.2$ & $33-102$ \\
AP $(\mathrm{UI} / \mathrm{L})$ & $112.9 \pm 144.7^{\mathrm{a}}$ & $153.3 \pm 126.8^{\mathrm{a}}$ & $20-220$ \\
CK $(\mathrm{UI} / \mathrm{L})$ & $357 \pm 397.9$ & $227.3 \pm 227.9$ & $5.5-8.5$ \\
Erythrocytes $(\mathrm{x} 10 / \mu \mathrm{L})$ & $5.4 \pm 1.9$ & $4.7 \pm 2.7$ & $12-18$ \\
Hemoglobin $(\mathrm{g} / \mathrm{dl})$ & $11.8 \pm 4.0$ & $10.2 \pm 5.1$ & $37-55$ \\
Hematocrit $(\%)$ & $36.2 \pm 12.0^{\mathrm{a}}$ & $31.5 \pm 16.0^{\mathrm{a}}$ & $200-500$ \\
Platelets $\left(\mathrm{x} 10^{3} / \mu \mathrm{L}\right)$ & $155.1 \pm 84.8$ & $101.1 \pm 111.2$ & 5 \\
\hline
\end{tabular}

Mean \pm Standard Deviation. ${ }^{2}$ Statistical difference between G1 and G2 (p<0.05). ${ }^{1}$ Jain, 1993; Kaneko et al., 1997.

SOLANO-GALLEGO et al., 2004; GIUNCHETTI et al., 2006; XAVIER et al., 2006), irrespective of the presence of the parasite. The presence of a large number of plasmocytes in the lymphoid tissues may be associated with hypergammaglobulinemia, usually found in LVC and EMC infections due to the activation of polyclonal B lymphocytes.

The degree of inflammatory reaction and reorganization of the extracellular matrix observed in this study, which was evidenced by reduced thick collagen fibers and increased thin collagen fibers, was not related with the parasite burden in the skin, unlike what has been observed in naturally CVL-infected and experimentally Leishmania-infected murines (ABREU-SILVA et al., 2004; GIUNCHETTI et al., 2006). The degradation and absence of collagen fibers in the reticular dermis were attributed more to the degree of tissue destruction produced by the inflammatory process than to the presence of parasites.

The discrete amastigote forms in the skin may be related to the time course of infection and/or the immunological status of the host. In fact, Leishmania dissemination to the skin in dogs and human beings appears to be a late event in the course of infection (HERWALDT, 1999; TRAVI et al., 2001; DOS SANTOS et al., 2004). Moreover, the presence of parasites in ear skin may be favored by injuries and auto-traumatism, which induce inflammatory reactions (TAFURI et al., 2001; XAVIER et al., 2006).

Co-infected dogs presented twice as many parasites in the skin than monoinfected dogs, probably due to the synergism between two infectious agents that infect mononuclear phagocytes, 
resulting in depression of the immune system and favoring parasite replication (MEKUZAS et al., 2009). In fact, E. canis causes a reduction in major histocompatibility complex of class II receptors (HARRUS et al., 2003), which could eventually enhance the clinical progression of CVL and thus increase the parasite burden. L. infantum may also impair the host's cellular and humoral immune response, which may favor the establishment or reactivation of a pre-existing E. canis infection (BARBIÉRI, 2006). The importance of monitoring co-infected dogs stems from the fact that the transmission of $L$. infantum is supported by the presence of parasites in the skin of infected animals (DEANE \& DEANE, 1955).

The low mean platelet counts detected in G1 and G2 animals have already been described in both CVL and CME (BULLA et al., 2004; CIARAMELLA et al., 2005; TERRAZZANO et al., 2006; CORTESE et al., 2009a). Thrombocytopenia and thrombocytopathy may result from vasculitis, increased platelet destruction following renal and/or hepatic failure, or anti-platelet antibodies. In particular, platelet-bound antibodies have been detected in the sera of dogs naturally infected with L. infantum and in experimentally induced $E$. canis infections (WANER et al., 2000; CORTESE et al., 2009b). According to Hildebrandt et al. (1973), microscopic hemorrhage areas are an evident feature in canine ehrlichiosis. In addition, the microhemorrhages observed in the spleen of dogs may be related to haemostatic abnormalities such as diminished platelet aggregation (CIARAMELLA et al., 2005; PETANIDES et al., 2008). The vascular wall fibroplasia found in lymphoid tissues may be a consequence of remodeling and hypertrophy of the vascular wall in response to the inflammatory process. Moreover, adherence of infected mononuclear cells to the vascular endothelium, which is characteristic of the acute phase of CVL and CME (PETANIDES et al., 2008), as well as immune complexes deposited in the vascular endothelium (ISMAIL et al., 2010; CORTESE et al., 2009a; CORTESE et al., 2009b), may contribute to this morphological change.

Hyperplasia and hypoplasia of the spleen white pulp observed in a $50 \%$ of the sampled animals have already been reported as a common event (VERESS et al., 1983). The dichotomy between these splenic changes may reflect different stages of the disease, according to the immune status of the individual, a common situation in natural infections. The increased number of arterioles (neovascularization) found in white pulp was also observed in dogs naturally infected with Leishmania (TASCA et al., 2009), but the angiogenesis has not yet been elucidated.

The granulomatous inflammation found in $50 \%$ of the sampled dogs is a characteristic pathological feature observed in intracellular parasite infections (ABBAS et al., 1994). Although granulomas may represent a step towards controlling the infection, the granulomatous inflammation found here can favor the survival and development of the parasites (MURRAY, 2001). The granulomas seem to reflect a persistent chronic inflammation in response to unquelled infection rather than protection against the infectious agent. This is supported by evidence that in granulomas, epithelioid cells secrete factors that inhibit the activation of macrophages and lymphocytes, and also secrete cytokines such as IL10, which favor the parasite's persistence in the tissue (BARRAL-NETTO et al., 1995; WILSON et al., 1996; MURRAY, 2001).

Mott cells observed in samples of skin, spleen and lymph node tissues are described as variant forms of plasma cells, which are replete with immunoglobulin located inside vesicular structures derived from dilated rough endoplasmic reticulum called Russell bodies (TARLINTON et al., 1992). The presence of this type of cell is attributed to the exacerbated activation of $B$ cells (plasmacytosis) associated with deficient immunoglobulin release (BAIN, 2009).

The elevated CK level found in groups G1 and G2 may be ascribed to inflammatory myopathy, as previously reported by Paciello et al. (2009) in dogs naturally infected with L. infantum. Changes in skeletal muscle tissues may be associated with immune-mediated phenomena due to the presence of immunecomplex, as well as the intense proliferation of amastigote forms of Leishmania within macrophages, which may act as a trigger of inflammatory response (PACIELLO et al., 2009).

The high AP level, mainly in co-infected dogs, may be related to liver injury, and to cholestasis, which has been described in human monocytic ehrlichiosis infections with Ehrlichia chaffeensis (KANEKO et al., 1997; SEHDEV; DUMLER, 2003). On the other hand, our study was conducted with captive animals subjected to stress and/or malnourishment, which predisposes them to a broad spectrum of infectious agents, reducing their body condition, etc. This vicious cycle contributes to hepatic damage and the consequent increase in AP.

The anemia observed in the dogs of this study may be attributed to chronic bleeding caused by thrombocytopenia, and/ or erythrolysis (hemolytic anemia) caused by anti-erythrocyte antibodies entering red blood cells sensitized by parasite epitopes. Also, their anemic condition can be attributed to the suppression of erythropoiesis in the bone marrow caused by intra-monocytic parasites (IKEDA-GARCIA et al., 2003; DA COSTA-VAL et al., 2007; MAHAJAN \& MARWAHA, 2007).

The varying degrees of inflammation and injury observed in both skin and lymphoid tissues of the sampled animals may be ascribed to a variation in the immune status of individual hosts. In the case of natural co-infections, host-parasite relationships are influenced not only by past and current exposure to one parasite but also to the presence and history of infection of the second parasite species (CATTADORI et al., 2008). Different outcomes resulting from concomitant infections are therefore observed. Furthermore, our findings revealed that dogs naturally and concomitantly infected with $L$. infantum and E. canis suffered extensive damage to tissues and iincreased number of amastigote forms of Leishmania in the skin, which may attract sand flies that cause infections.

\section{References}

Abbas AK, Lichtman AH, Pober JS. Regulation of immune responses. In: Abbas AK, Lichtman AH, Pober JS, editors. Cellular and molecular immunology. 2nd ed. Philadelphia: Saunders; 1994. p. 205-221.

Abreu-Silva AL, Calabrese KS, Mortara RA, Tedesco RC, Cardoso FO, Carvalho LO, et al. Extracellular matrix alterations in experimental 
murine Leishmania (L.) amazonensis infection. Parasitology 2004; 128(Pt 4): 385-390. http://dx.doi.org/10.1017/S0031182003004621. PMid:15151143

Alexander J, Bryson K. T helper (h)1/Th2 and Leishmania: paradox rather than paradigm. Immunol Lett 2005; 99(1): 17-23. http://dx.doi. org/10.1016/j.imlet.2005.01.009. PMid:15894106

Alexander J, Brombacher F. T helper1/t helper2 cells and resistance/ susceptibility to Leishmania infection: is this paradigm still relevant? Front Immunol 2012; 3: 80. http://dx.doi.org/10.3389/fimmu.2012.00080. PMid:22566961

Bain BJ. Russell bodies and Mott cells. Am J Hematol 2009; 84(8): 516. http://dx.doi.org/10.1002/ajh.21397. PMid:19384941

Barbiéri CL. Immunology of canine leishmaniasis. Parasite Immunol 2006; 28(7): 329-337. http://dx.doi.org/10.1111/j.1365-3024.2006.00840.x. PMid:16842269

Barral-Netto M, da Silva JS, Barral A, Reed S. Up-regulation of T helper 2 and down-regulation of $\mathrm{T}$ helper 1 cytokines during murine retrovirus-induced immunodeficiency syndrome enhances susceptibility of a resistant mouse strain to Leishmania amazonensis. Am J Pathol 1995; 146(3): 635-642. PMid:7887446.

Bulla C, Kiomi Takahira R, Araújo JP Jr, AparecidaTrinca L, Lopes RS, Wiedmeyer CE. The relationship between the degree of thrombocytopenia and infection with Ehrlichia canis in an endemic area. Vet Res 2004; 35(1): 141-146. http://dx.doi.org/10.1051/vetres:2003038. PMid:15099511

Castro IP, Sousa MVC, Magalhães GM, Mundim AV, Noleto PG, Paula $\mathrm{MBC}$, et al. Perfil hepático e protéico em cães com leishmaniose visceral. Biosci J 2012; 28(5): 799-804.

Cattadori IM, Boag B, Hudson PJ. Parasite co-infection and interaction as drivers of host heterogeneity. Int J Parasitol 2008; 38(3-4): 371-380. http://dx.doi.org/10.1016/j.ijpara.2007.08.004. PMid:17936286

Ciaramella P, Pelagalli A, Cortese L, Pero ME, Corona M, Lombardi $\mathrm{P}$, et al. Altered platelet aggregation and coagulation disorders related to clinical findings in 30 dogs naturally infected by Leishmania infantum. Vet J2005; 169(3): 465-467. http://dx.doi.org/10.1016/j.tvjl.2004.03.009. PMid:15848791

Cortese L, Pelagalli A, Piantedosi D, Cestaro A, Di Loria A, Lombardi P, et al. Effects of therapy on haemostasis in dogs infected with Leishmania infantum, Ehrlichia canis, or both combined. Vet Rec 2009a; 164(14): 433-434. http://dx.doi.org/10.1136/vr.164.14.433. PMid:19346544

Cortese L, Sica M, Piantedosi D, Ruggiero G, Pero ME, Terrazzano $\mathrm{G}$, et al. Secondary immune-mediated thrombocytopenia in dogs naturally infected by Leishmania infantum. Vet Rec 2009b; 164(25): 778-782. http://dx.doi.org/10.1136/vr.164.25.778. PMid:19542552

Cox FE. Concomitant infections, parasites and immune responses. Parasitology 2001;122(S1, Suppl): S23-S38. http://dx.doi.org/10.1017/ S003118200001698X. PMid:11442193

da Costa-Val AP, Cavalcanti RR, de Figueiredo Gontijo N, Michalick MS, Alexander B, Williams P, et al. Canine visceral leishmaniasis: relationships between clinical status, humoral immune response, haematology and Lutzomyia (Lutzomyia) longipalpis infectivity. Vet J 2007; 174(3): 636643. http://dx.doi.org/10.1016/j.tvjl.2006.11.006. PMid:17229582

Day MJ. One health: the importance of companion animal vector-borne diseases. Parasit Vectors 2011; 4(1): 49. http://dx.doi.org/10.1186/17563305-4-49. PMid:21489237
Deane LM, Deane MP. Observações preliminares sobre a importância comparativa do homem, do cáo e da raposa (Lycalopex vetulus) como reservatório da Leishmania donovani em área endêmica de Calazar, no Ceará. O Hospital 1955; 48: 61-76.

de Sousa KC, André MR, Herrera HM, de Andrade GB, Jusi MM, dos Santos LL, et al. Molecular and serological detection of tick-borne pathogens in dogs from an area endemic for Leishmania infantum in Mato Grosso do Sul, Brazil. Rev Bras Parasitol Vet 2013; 22(4): 525-531. http:// dx.doi.org/10.1590/S1984-29612013000400012. PMid:24473877

De Tommasi AS, Otranto D, Dantas-Torres F, Capelli G, Breitschwerdt EB, de Caprariis D. Are vector-borne pathogen co-infections complicating the clinical presentation in dogs? Parasit Vectors 2013; 6(1): 97. http:// dx.doi.org/10.1186/1756-3305-6-97. PMid:23587324

dos-Santos WL, David J, Badaró R, de-Freitas LA. Association between skin parasitism and a granulomatous inflammatory pattern in canine visceral leishmaniosis. Parasitol Res 2004; 92(2): 89-94. http://dx.doi. org/10.1007/s00436-003-1016-1. PMid:14610666

Garraud O, Perraut R, Riveau G, Nutman TB. Class and subclass selection in parasite-specific antibody responses. Trends Parasitol 2003; 19(7): 300-304. http://dx.doi.org/10.1016/S1471-4922(03)00139-9. PMid:12855380

Giunchetti RC, Mayrink W, Genaro O, Carneiro CM, Corrêa-Oliveira $\mathrm{R}$, Martins-Filho OA, et al. Relationship between canine visceral leishmaniosis and the Leishmania (Leishmania) chagasi burden in dermal inflammatory foci. J Comp Pathol 2006; 135(2-3): 100-107. http:// dx.doi.org/10.1016/j.jcpa.2006.06.005. PMid:16959259

Harrus S, Waner T, Friedmann-Morvinski D, Fishman Z, Bark $\mathrm{H}$, Harmelin A. Down-regulation of MHC class II receptors of DH82 cells, following infection with Ehrlichia canis. Vet Immunol Immunopathol 2003; 96(3-4): 239-243. http://dx.doi.org/10.1016/j. vetimm.2003.08.005. PMid:14592737

Herwaldt BL. Leishmaniasis. Lancet 1999; 354(9185): 1191-1199. http://dx.doi.org/10.1016/S0140-6736(98)10178-2. PMid:10513726

Hildebrandt PK, Huxsoll DL, Walker JS, Nims RM, Taylor R, Andrews M. Pathology of canine ehrlichiosis (tropical canine pancytopenia). Am $J$ Vet Res 1973; 34(10): 1309-1320. PMid:4542936.

Ikeda-Garcia FA, Ciarlini PC, Feitosa MM, Gonçalves ME, Luvizotto MCR, Lima VMF. Perfil hematológico de cães naturalmente infectados por Leishmania chagasi no município de Araçatuba, São Paulo: estudo retrospectivo de 191 casos. Clin Vet 2003; 47: 42-48.

Ismail N, Bloch KC, McBride JW. Human ehrlichiosis and anaplasmosis. Clin Lab Med 2010; 30(1): 261-292. http://dx.doi.org/10.1016/j. cll.2009.10.004. PMid:20513551

Jain NC. Essentials of veterinary hematology. Philadelphia: Lea \& Febiger; 1993

Kaneko JJ, Harvey JW, Bruss ML. Clinical biochemistry of domestic animals. San Diego: Academic Press; 1997.

Luna LG. Manual of histological staining methods of the Armed Forces Institute of Pathology. New York: McGraw Hill; 1968.

Mahajan V, Marwaha RK. Immune mediated hemolysis in visceral leishmaniasis. J Trop Pediatr 2007; 53(4): 284-286. http://dx.doi. org/10.1093/tropej/fmm018. PMid:17483492

Mekuzas Y, Gradoni L, Oliva G, Foglia Manzillo V, Baneth G. Ehrlichia canis and Leishmania infantum co-infection: a 3-year longitudinal study 
in naturally exposed dogs. Clin Microbiol Infect 2009;15(Suppl 2): 30-31. http://dx.doi.org/10.1111/j.1469-0691.2008.02150.x. PMid:19416288

Murray HW. Tissue granuloma structure-function in experimental visceral leishmaniasis. Int J Exp Pathol 2001; 82(5): 249-267. http:// dx.doi.org/10.1046/j.1365-2613.2001.00199.x. PMid:11703536

Nicholson WL, Allen KE, McQuiston JH, Breitschwerdt EB, Little SE. The increasing recognition of rickettsial pathogens in dogs and people. Trends Parasitol 2010; 26(4): 205-212. http://dx.doi.org/10.1016/j. pt.2010.01.007. PMid:20207197

Paciello O, Oliva G, Gradoni L, Manna L, Foglia Manzillo V, Wojcik $S$, et al. Canine inflammatory myopathy associated with Leishmania infantum infection. Neuromuscul Disord 2009; 19(2): 124-130. http:// dx.doi.org/10.1016/j.nmd.2008.10.013. PMid:19084398

Petanides TA, Koutinas AF, Mylonakis ME, Day MJ, Saridomichelakis MN, Leontides LS, et al. Factors associated with the occurrence of epistaxis in natural canine leishmaniasis (Leishmania infantum). J Vet Intern Med 2008; 22(4): 866-872. http://dx.doi.org/10.1111/j.19391676.2008.0129.x. PMid:18564224

Pinelli E, Killick-Kendrick R, Wagenaar J, Bernadina W, del Real G, Ruitenberg J. Cellular and humoral immune responses in dogs experimentally and naturally infected with Leishmania infantum. Infect Immun 1994; 62(1): 229-235. PMid:8262632.

Rey L. Parasitologia. Rio de Janeiro: Guanabara Kooga; 2001.

Ridley DS, Ridley MJ. The evolution of the lesion in cutaneous leishmaniasis. J Pathol 1983; 141(1): 83-96. http://dx.doi.org/10.1002/ path.1711410109. PMid:6620010

Sehdev AE, Dumler JS. Hepatic pathology in human monocytic ehrlichiosis. Ehrlichia chaffeensis infection. Am J Clin Pathol 2003; 119(6): 859-865. http://dx.doi.org/10.1309/F7EAB5P7321716LJ. PMid:12817434

Solano-Gallego L, Fernández-Bellon H, Morell P, Fondevila D, Alberola J, Ramis A, et al. Histological and immunohistochemical study of clinically normal skin of Leishmania infantum-infected dogs. J Comp Pathol 2004; 130(1): 7-12. http://dx.doi.org/10.1016/S0021-9975(03)00063-X. PMid:14693119

Tafuri WL, de Oliveira MR, Melo MN, Tafuri WL. Canine visceral leishmaniosis: a remarkable histopathological picture of one case reported from Brazil. Vet Parasitol 2001; 96(3): 203-212. http://dx.doi. org/10.1016/S0304-4017(00)00436-2. PMid:11240094
Tarlinton D, Förster I, Rajewsky K. An explanation for the defect in secretion of IgM Mott cells and their predominant occurrence in the Ly-1 B cell compartment. Eur J Immunol 1992; 22(2): 531-539. http:// dx.doi.org/10.1002/eji.1830220236. PMid:1537387

Tasca KI, Buzetti WA, Tenório MS, Paulan SC, Lima FL, de Queiroz NM, et al. [Parasitological, immunohistochemical and histopathological study for Leishmania chagasi detection in splenic tissues of dogs with visceral leishmaniasis]. Rev Bras Parasitol Vet 2009; 18(1): 27-33. http:// dx.doi.org/10.4322/rbpv.01801005. PMid:19500457

Terrazzano G, Cortese L, Piantedosi D, Zappacosta S, Di Loria A, Santoro D, et al. Presence of anti-platelet IgM and IgG antibodies in dogs naturally infected by Leishmania infantum. Vet Immunol Immunopathol 2006; 110(3-4): 331-337. http://dx.doi.org/10.1016/j. vetimm.2005.11.001. PMid:16406554

Travi BL, Tabares CJ, Cadena H, Ferro C, Osorio Y. Canine visceral leishmaniasis in Colombia: relationship between clinical and parasitologic status and infectivity for sand flies. Am J Trop Med Hyg 2001; 64(3-4): 119-124. PMid:11442205.

Unver A, Perez M, Orellana N, Huang H, Rikihisa Y. Molecular and antigenic comparison of Ehrlichia canis isolates from dogs, ticks, and a human in Venezuela. J Clin Microbiol 2001; 39(8): 2788-2793. http:// dx.doi.org/10.1128/JCM.39.8.2788-2793.2001. PMid:11473993

Veress B, Abdalla RE, El Hassan AM. Visceral spreading depletion of thymus-dependent regions and amyloidosis in mice and hamsters infected intradermally with Leishmania isolated from Sudanese cutaneous leishmaniasis. Br J Exp Pathol 1983; 64(5): 505-514. PMid:6605763.

Waner T, Leykin I, Shinitsky M, Sharabani E, Buch H, Keysary A, et al. Detection of platelet-bound antibodies in beagle dogs after artificial infection with Ehrlichia canis. Vet Immunol Immunopathol 2000; 77(12): 145-150. http://dx.doi.org/10.1016/S0165-2427(00)00225-7. PMid:11068072

Wilson ME, Sandor M, Blum AM, Young BM, Metwali A, Elliott $\mathrm{D}$, et al. Local suppression of IFN-gamma in hepatic granulomas correlates with tissue-specific replication of Leishmania chagasi. J Immunol 1996; 156(6): 2231-2239. PMid:8690913.

Xavier SC, de Andrade HM, Monte SJ, Chiarelli IM, Lima WG, Michalick MS, et al. Comparison of paraffin-embedded skin biopsies from different anatomical regions as sampling methods for detection of Leishmania infection in dogs using histological, immunohistochemical and PCR methods. BMC Vet Res 2006; 2(1): 17. http://dx.doi. org/10.1186/1746-6148-2-17. PMid:16762067 